\title{
Initial injectable therapy in type 2 diabetes: Key considerations when choosing between glucagon-like peptide 1 receptor agonists and insulin
}

\author{
Anastasia-Stefania Alexopoulos ${ }^{\mathrm{a}, *}$, John B. Buse ${ }^{\mathrm{b}}$ \\ ${ }^{a}$ Duke University Medical Center, Durham, NC, United States \\ ${ }^{\mathrm{b}}$ University of North Carolina, Chapel Hill, NC, United States
}

\section{A R T I C L E I N F O}

\section{Article history:}

Received 14 April 2019

Received in revised form 17 June 2019

Accepted 24 June 2019

\begin{abstract}
A B S T R A C T
Managing type 2 diabetes is complex and necessitates careful consideration of patient factors such as engagement in self-care, comorbidities and costs. Since type 2 diabetes is a progressive disease, many patients will require injectable agents, usually insulin. Recent ADA-EASD guidelines recommend glucagon-like peptide 1 receptor agonists (GLP-1 RAs) as first injectable therapy in most cases. The basis for this recommendation is the similar glycemic efficacy of GLP-1 RAs and insulin, but with GLP-1 RAs promoting weight loss instead of weight gain, at lower hypoglycemia risk, and with cardiovascular benefits in patients with pre-existing cardiovascular disease. GLP-1 RAs also reduce burden of glucose self-monitoring. However, tolerability and costs are important considerations, and notably, rates of drug discontinuation are often higher for GLP-1 RAs than basal insulin. To minimize risk of gastrointestinal symptoms patients should be started on lowest doses of GLP-1 RAs and up-titrated slowly. Overall healthcare costs may be lower with GLP-1 RAs compared to insulin. Though patient-level costs may still be prohibitive, GLP-1 RAs can replace 50-80 units of insulin daily and reduce costs associated with glucose self-monitoring. Decisions regarding initiating injectable therapy should be individualized. This review provides a framework to guide decision-making in the real-world setting.
\end{abstract}

\section{Contents}

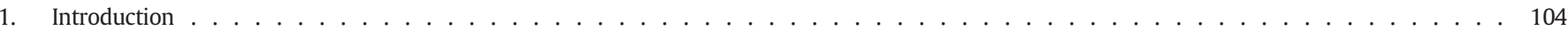

2. Glycemic efficacy of injectable agents in diabetes. . . . . . . . . . . . . . . . . . . . . . . . . . . . . . . . . . . . . . . 105

2.1. GLP-1 receptor agonists versus basal insulin. . . . . . . . . . . . . . . . . . . . . . . . . . . . . . . . . 105

2.2. GLP-1 receptor agonist versus prandial insulin. . . . . . . . . . . . . . . . . . . . . . . . . . . . . 105

2.3. Combining GLP-1 receptor agonists and insulin . . . . . . . . . . . . . . . . . . . . . . . . . . . . 105

2.4. Glycemic efficacy versus effectiveness . . . . . . . . . . . . . . . . . . . . . . . . . . . . . 105

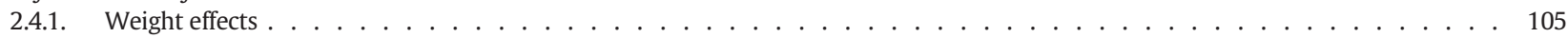

2.4.2. Hypoglycemia . . . . . . . . . . . . . . . . . . . . . . . . . . . 107

2.4.3. Cardiovascular outcomes trials. . . . . . . . . . . . . . . . . . . . . . . . . . 107

2.4.4. Administration of injectable therapies . . . . . . . . . . . . . . . . . . . . . . . . . . 108

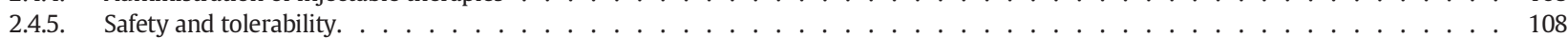

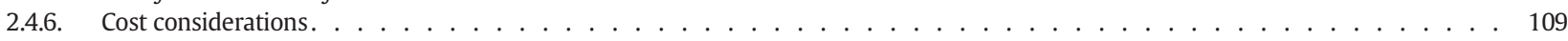

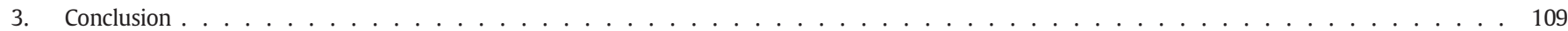

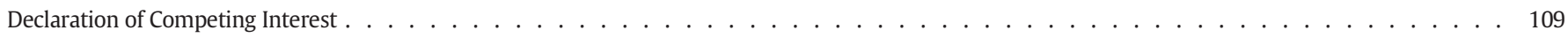

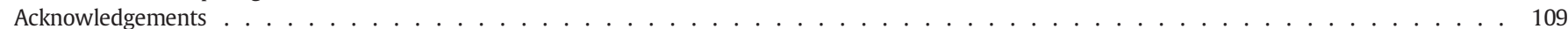

Author contributions . . . . . . . . . . . . . . . . . . . . . . . . . . . . . . . . . . . . 109

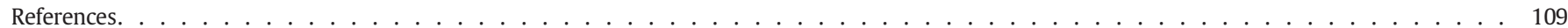

\section{Introduction}

* Corresponding author.

E-mail address: asa61@duke.edu (A.-S. Alexopoulos).
Management of type 2 diabetes is complex, and quality care necessitates careful consideration of patient factors such as preferences, 
engagement in self-care, comorbidities and costs. Goals of diabetes care include preventing diabetes-related complications and maintaining or enhancing quality of life. Since type 2 diabetes is a progressive disease, achieving these goals will often require intensification to injectable therapy. Classically this has been accomplished with insulin. One in four patients will require insulin within 6 years of starting oral glucoselowering therapies $[1,2]$. In the United States, insulin was the only injectable option for diabetes until 2005, when exenatide, a glucagon-like peptide 1 receptor agonist (GLP-1 RA), was approved for use by the Food and Drug Association (FDA). Since then, five additional GLP-1 RAs have been approved for use: lixisenatide, albiglutide, dulaglutide, liraglutide and semaglutide; though albiglutide was withdrawn from the market in 2018. These agents can be broadly characterized as xenopeptides (exenatide and lixisenatide), human GLP-1 analogs (liraglutide and semaglutide), and fusion peptides (albiglutide and dulaglutide). The xenopeptides are short-acting, though exenatide is also available in a long-acting weekly formulation. Liraglutide administered once daily and the four once-weekly formulations (albiglutide, dulaglutide, weekly exenatide, and semaglutide) provide longer durations of action. Meanwhile, insulin options have also expanded to include human insulins, multiple rapid- and long-acting insulin analogs, concentrated formulations and premixes. With an expanding armamentarium of injectable glucose-lowering agents, it is important for providers and patients to weigh risks and benefits of each option and to examine patient factors which may guide the choice of one agent over another.

The 2018 American Diabetes Association and the European Association for the study of Diabetes (ADA-EASD) consensus statement on the management of type 2 diabetes recognized GLP-1 RAs as first-line injectable therapy before basal insulin, except when 1) hemoglobin A1c (HbA1c) is $>11 \%, 2$ ) there is evidence of catabolism, such as weight loss, polyuria and polydipsia, or 3 ) there is concern that a patient may have type 1 or pancreatogenic diabetes [3]. GLP-1 RAs emerged in preference to insulin as initial injectable therapy because of comparable efficacy but with weight loss instead of weight gain, less hypoglycemia, and in the setting of cardiovascular disease, benefits on myocardial infarction, stroke and cardiovascular death [3]. However, in many cases, rates of drug discontinuation are higher with GLP-1 RAs than with basal insulin [4,5]. In this article we explore issues related to injectable glucose-lowering therapies, and provide readers with a guide to using them in everyday clinical practice.

\section{Glycemic efficacy of injectable agents in diabetes}

\subsection{GLP-1 receptor agonists versus basal insulin}

GLP-1 receptor agonists induce glucose-dependent insulin secretion, suppress glucagon secretion, slow gastric emptying and enhance satiety [6]. Evidence suggests that glycemic efficacy is greatest for semaglutide once-weekly, followed in descending order by dulaglutide, liraglutide, exenatide, albiglutide and lixisenatide [3,7]. Multiple studies have compared the efficacy of GLP-1 RAs versus basal insulins glargine, detemir and degludec in patients inadequately controlled on oral glucoselowering therapies (Table 1) [8,9]. In general, the glycemic efficacy of long-acting GLP-1 RAs has been greater than basal insulin. For instance, in a head-to-head trial of semaglutide once-weekly versus glargine once-daily [10], change from baseline HbA1c with semaglutide was double that observed with glargine. Even in studies that have compared glucose lowering in patients with $\mathrm{HbA} 1 \mathrm{c}$ up to $11 \%$, the equivalent or greater efficacy of GLP-1 RAs to basal insulin has been clearly demonstrated [9].

\subsection{GLP-1 receptor agonist versus prandial insulin}

GLP-1 RAs have the ability to reduce fasting and post-prandial hyperglycemia. The short-acting GLP-1 RAs (exenatide twice-daily and lixisenatide) have considerable post-prandial efficacy at the meals consumed immediately after injection, but little fasting efficacy. The long- acting GLP-1 RAs exhibit greater impact on fasting glucose levels $[11,12]$. Therefore, in addition to exploring GLP-1 RAs as alternatives to basal insulin, they have been examined in comparison to prandial and premixed insulins (Table 2), both in the presence and absence of basal insulin therapy. In both cases, GLP-1 RAs appear to have similar efficacy as insulin. As such, GLP-1 RAs are effective as alternatives to rapid-acting insulins, although prandial insulin alone is rarely prescribed as first injectable therapy in practice.

\subsection{Combining GLP-1 receptor agonists and insulin}

While stepwise addition of glucose-lowering agents is generally preferred over initial combination therapy, the latter can be considered when patients present with HbA1c levels well above target (i.e. $\geq 1.5 \%$ ) [3]. In 2016 the FDA approved two combination products with fixed ratios of GLP-1 RA and basal insulin: insulin degludec plus liraglutide [13] and insulin glargine plus lixisenatide [14]. These fixed-dose combination products appear to be more effective at lowering HbA1c as compared to escalation of basal insulin alone (difference $-0.53 \%, 95 \% \mathrm{CI}$ $-0.66,-0.40$, p-value $<0.001$ ), with equivalent hypoglycemia risk and less weight gain [15]. Thus, fixed-dose GLP-1 RA/basal insulin formulations can be considered as first injectable therapy in select patients with uncontrolled diabetes, however it is important to consider medication costs and less flexibility of dosing when opting for this approach.

\subsection{Glycemic efficacy versus effectiveness}

While the efficacy of GLP-1 RA therapy and insulin appear similar in randomized controlled trials (RCTs), it is worthwhile noting that patients enrolled in RCTs are highly selected individuals who are likely more motivated, adherent, and supported, thus are not reflective of populations encountered in practice. As such, the effectiveness of glucose-lowering agents in real-world settings varies substantially to the efficacy noted in RCTs [4]. A recent study compared the efficacy of GLP-1 RAs (exenatide, liraglutide) between RCTs and administrative claims data (linked to electronic health records), and found a mean change in $\mathrm{HbA1c}$ of $-1.30 \%$ in RCTs, versus only $-0.52 \%$ in real-world data [16]. Lack of adherence accounted for $75 \%$ of this discrepancy [16]. Persistence rates in realworld settings vary depending on the study, though rates generally decrease with longer study duration [4]. Factors influencing adherence and persistence to GLP-1 RA therapy are likely similar, including cost considerations, side effects, convenience of dosing and administration, as well as marketplace issues such as safety concerns advertised by lawyers and changing coverage patterns of various health plans. Of note, even in the context RCTs comparing once-daily GLP-1 RA (liraglutide) to once-daily basal insulin, discontinuation rates for GLP-1 RA were higher [17]. This suggests that side effects of GLP-1 RAs are at least in part responsible for lack of persistence to therapy, since administration is similar between once-daily liraglutide and basal insulin, and cost issues are unlikely to underlie medication discontinuation in the context of an RCT. In terms of predicting patterns of adherence and persistence, a recent study by Durden et al. [18] found that patients were more likely to adhere to GLP1 RA therapy over an 18 month period if they experienced an HbA1c reduction of $>1 \%$ (OR $1.59,95 \% \mathrm{CI} 1.36,1.85)$ or body weight reduction of $>3 \%$ (OR 1.18, 95\% CI 1.02, 1.36) within 3-6 months of drug initiation, compared to those without an early response. These early responders also had significantly lower likelihood of discontinuation compared to patients without early response (HbA1c reduction $<1 \%$ : OR 0.62 , 95\% CI 0.53 , 0.72 ; weight reduction $<3 \%$ : OR $0.81,95 \%$ CI $0.70,0.94$ ) [18].

Though theoretically insulin has limitless glycemic efficacy, in practice, its titration is limited by hypoglycemia and/or fear of hypoglycemia (Table 3).

\subsubsection{Weight effects}

A major advantage of GLP-1 RA therapy over insulin is its ability to promote satiety and clinically meaningful weight reduction, while insulin treatment is often associated with weight gain. This is exceedingly 
Table 1

HbA1c change, weight change and rate of hypoglycemia in randomized controlled trials comparing GLP-1 receptor agonist to basal insulin.

\begin{tabular}{|c|c|c|c|c|c|c|}
\hline Clinical trial & $\begin{array}{l}\text { Back-ground } \\
\text { therapy }\end{array}$ & $\begin{array}{l}\text { Study } \\
\text { duration }\end{array}$ & Treatment & $\begin{array}{l}\triangle \text { HbA1c during } \\
\text { study }\end{array}$ & $\begin{array}{l}\Delta \text { Weight (kg) during } \\
\text { study }\end{array}$ & Rate of hypoglycemia \\
\hline $\begin{array}{l}\text { Davies et al. [61] } \\
\text { (HEELA) }\end{array}$ & Met, SU, TZD & 26 weeks & $\begin{array}{l}\text { Exenatide } 5-10 \mu \mathrm{g} \text { BID } \\
\text { Glargine qD }\end{array}$ & $\begin{array}{l}-1.3 \\
-1.3\end{array}$ & $\begin{array}{l}-2.7^{* * * *} \\
+3.0\end{array}$ & $\begin{array}{c}50 \%\left(11.9 \%^{\mathrm{a}}\right) \\
59.6 \%\left(29.8 \%^{\mathrm{a}}\right)\end{array}$ \\
\hline $\begin{array}{l}\text { Diamant et al. [62] } \\
\text { (DURATION-3) }\end{array}$ & Met \pm SU & 26 weeks & $\begin{array}{l}\text { Exenatide } 2 \mathrm{mg} \mathrm{qW} \\
\text { Glargine } \mathrm{qD}\end{array}$ & $\begin{array}{l}-1.5^{*} \\
-1.3\end{array}$ & $\begin{array}{l}-2.6^{* * *} \\
+1.4\end{array}$ & $\begin{array}{c}8 \% \\
26 \%\end{array}$ \\
\hline $\begin{array}{l}\text { Diamant et al. [63] } \\
\text { (DURATION-3 } \\
\text { extension) }\end{array}$ & Met $\pm \mathrm{SU}$ & 84 weeks & $\begin{array}{l}\text { Exenatide } 2 \text { mg weekly } \\
\text { Glargine } \mathrm{qD}\end{array}$ & $\begin{array}{l}-1.2^{*} \\
-1.0\end{array}$ & $\begin{array}{l}-2.1^{* * *} \\
+2.4\end{array}$ & $\begin{array}{c}24 \% \text { if on SU, } 8 \% \text { if on Met } \\
54 \% \text { if on SU } \\
32 \% \text { if on Met }\end{array}$ \\
\hline $\begin{array}{l}\text { Diamant et al. [64] } \\
\text { (DURATION-3 } \\
\text { extension) }\end{array}$ & Met $\pm \mathrm{SU}$ & 156 weeks & $\begin{array}{l}\text { Exenatide } 2 \text { mg weekly } \\
\text { Glargine qD }\end{array}$ & $\begin{array}{l}-1.0^{*} \\
-0.8\end{array}$ & $\begin{array}{l}-2.5^{* * *} \\
+2.0\end{array}$ & $\begin{array}{l}0.3 \text { events/pt/yr } \\
0.9 \text { events/pt/yr }\end{array}$ \\
\hline Heine et al. [65] & Met, SU & 26 weeks & $\begin{array}{l}\text { Exenatide } 5-10 \mu \mathrm{g} \text { BID } \\
\text { Glargine qD }\end{array}$ & $\begin{array}{l}-1.1 \\
-1.1\end{array}$ & $\begin{array}{l}-2.3 \\
+1.8\end{array}$ & $\begin{array}{c}7.3 \text { events } / \mathrm{pt} / \mathrm{yr}\left(0.9^{\mathrm{a}}\right) \\
6.3 \text { events/pt/yr } \\
\left(2.4^{\mathrm{a}}\right)\end{array}$ \\
\hline Inagaki et al. [66] & Met \pm TZD & 26 weeks & $\begin{array}{l}\text { Exenatide } 5-10 \mu \mathrm{g} \text { BID } \\
\text { Glargine qD }\end{array}$ & $\begin{array}{l}-1.1^{* * *} \\
-0.7\end{array}$ & $\begin{array}{l}-1.7^{* * *} \\
+0.3\end{array}$ & $\begin{array}{c}9.3 \%\left(0.9 \%^{\mathrm{a}}\right) \\
12.3 \%\left(10.4 \%^{\mathrm{a}}\right)\end{array}$ \\
\hline Araki et al. [67] & Met $\pm \mathrm{SU}$ & 26 weeks & $\begin{array}{l}\text { Dulaglutide } 0.75 \text { mg qW } \\
\text { Glargine qD }\end{array}$ & $\begin{array}{l}-1.4^{* * *} \\
-0.9\end{array}$ & $\begin{array}{l}-0.50^{* * *} \\
+0.9\end{array}$ & $\begin{array}{l}26 \% \\
48 \%\end{array}$ \\
\hline $\begin{array}{l}\text { Blonde et al. [68] } \\
\text { (AWARD-4) }\end{array}$ & Met, Lispro & 52 weeks & Dulaglutide $0.75 / 1.5 \mathrm{mg} \mathrm{qW}$ & $\begin{array}{l}0.75 \mathrm{mg}:-1.6^{*} \\
1.5 \mathrm{mg}:-1.6^{* *}\end{array}$ & $\begin{array}{l}0.75 \mathrm{mg}:+0.2^{* * * *} \\
1.5 \mathrm{mg}:-0.9^{* * *}\end{array}$ & $3 \%$ \\
\hline & & & Glargine qD & -1.4 & +2.3 & $5.1 \%$ \\
\hline $\begin{array}{l}\text { D'Alessio et al. [17] } \\
\text { (EAGLE) }\end{array}$ & Met $\pm \mathrm{SU}$ & 24 weeks & $\begin{array}{l}\text { Liraglutide } 0.6-1.8 \mathrm{mg} \text { qD } \\
\text { Glargine } \mathrm{qD}\end{array}$ & $\begin{array}{l}-1.8 \\
-1.9^{*}\end{array}$ & $\begin{array}{l}-3.0^{* * *} \\
+2.0\end{array}$ & $\begin{array}{l}18 \% \\
45 \%\end{array}$ \\
\hline $\begin{array}{l}\text { Giorgino et al. [69] } \\
\text { (AWARD-2) }\end{array}$ & Met, SU & 78 weeks & Dulaglutide $0.75 / 1.5 \mathrm{mg} \mathrm{qW}$ & $\begin{array}{l}0.75 \mathrm{mg}:-0.8^{* * * *} \\
1.5 \mathrm{mg}:-1.1^{* * *}\end{array}$ & $\begin{array}{l}0.75 \mathrm{mg}:-1.3^{* * *} \\
1.5 \mathrm{mg}:-1.9^{* * *}\end{array}$ & $\begin{array}{l}0.75 \mathrm{mg}: 54.4 \% \\
1.5 \mathrm{mg}: 55.3 \%\end{array}$ \\
\hline $\begin{array}{l}\text { Russell-Jones et al. [70] } \\
\text { (LEAD-5) }\end{array}$ & Met, SU & 26 weeks & $\begin{array}{l}\text { Glargine qD } \\
\text { Liraglutide } 1.8 \mathrm{mg} \mathrm{qD} \\
\text { Glargine qD }\end{array}$ & $\begin{array}{l}-0.6 \\
-1.3^{* *} \\
-1.1\end{array}$ & $\begin{array}{c}+1.4 \\
-1.8^{* * *} \\
+1.6\end{array}$ & $\begin{array}{c}69.1 \% \\
2.3 \text { events/pt/yr } \\
3.1 \text { events/pt/yr }\end{array}$ \\
\hline Davies et al. [71] & Met \pm SU & 26 weeks & $\begin{array}{l}\text { Exenatide } 2 \text { mg weekly } \\
\text { Detemir qD or BID }\end{array}$ & $\begin{array}{l}-1.3^{* * *} \\
-0.9\end{array}$ & $\begin{array}{l}-2.7^{* * * *} \\
+0.8\end{array}$ & $\begin{array}{l}6 \% \\
7 \%\end{array}$ \\
\hline $\begin{array}{l}\text { Gough et al. [72] } \\
\text { (DUAL-I) }\end{array}$ & Met \pm TZD & 26 weeks & $\begin{array}{l}\text { Liraglutide } 0.6-1.8 \mathrm{mg} \text { qD } \\
\text { Degludec qD }\end{array}$ & $\begin{array}{l}-1.3 \\
-1.4\end{array}$ & $\begin{array}{l}-3.0 \\
+1.6\end{array}$ & $\begin{array}{l}0.2 \text { events/pt/yr } \\
2.6 \text { events/pt/yr }\end{array}$ \\
\hline $\begin{array}{l}\text { Gough et al. [73] } \\
\text { (DUAL-I extension) }\end{array}$ & Met \pm TZD & 52 weeks & $\begin{array}{l}\text { Liraglutide } 0.6-1.8 \mathrm{mg} \mathrm{qD} \\
\text { Degludec qD }\end{array}$ & $\begin{array}{l}-1.2 \\
-1.4\end{array}$ & $\begin{array}{l}-3.0 \\
+2.3\end{array}$ & $\begin{array}{l}1.9 \text { events/pt/yr } \\
2.8 \text { events/pt/yr }\end{array}$ \\
\hline $\begin{array}{l}\text { Weissman et al. [74] } \\
\text { (HARMONY-4) }\end{array}$ & Met \pm SU & 52 weeks & $\begin{array}{l}\text { Albiglutide } 30-50 \mathrm{mg} \mathrm{qW} \\
\text { Glargine } \mathrm{qD}\end{array}$ & $\begin{array}{l}-0.7 \\
-0.8\end{array}$ & $\begin{array}{l}-1.1^{* * *} \\
+1.6\end{array}$ & $\begin{array}{l}17.5 \% \\
27.4 \%\end{array}$ \\
\hline $\begin{array}{l}\text { Aroda et al. [10] } \\
\text { (SUSTAIN-4) }\end{array}$ & Met $\pm \mathrm{SU}$ & 30 weeks & $\begin{array}{l}\text { Semaglutide } 0.5 / 1 \mathrm{mg} \mathrm{qW} \\
\text { Glargine qD }\end{array}$ & $\begin{array}{l}0.5 \mathrm{mg}:-1.2^{* * *} \\
1 \mathrm{mg}:-1.6^{* * *} \\
\quad-0.8\end{array}$ & $\begin{array}{l}0.5 \mathrm{mg}:-3.5^{* * *} \\
1 \mathrm{mg}:-5.2^{* * *} \\
\quad+1.15\end{array}$ & $\begin{array}{c}0.5 \mathrm{mg}: 4 \%^{\mathrm{b}} \\
1 \mathrm{mg}: 6 \%^{\mathrm{b}} \\
11 \%\end{array}$ \\
\hline
\end{tabular}

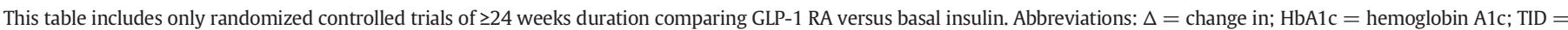

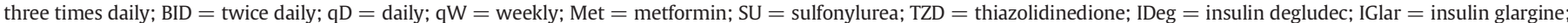
events/pt/yr $=$ events per patient per year. Statistical significance for HbA1c and weight changes: ${ }^{*}=\mathrm{p}$-value $<0.05,{ }^{* *}=p$-value $<0.01,{ }^{* * *}=\mathrm{p}$-value $<0.001$.

a Nocturnal hypoglycemia.

b Severe or documented hypoglycemia, otherwise all hypoglycemia rates are minor or overall reported daytime hypoglycemia.

Table 2

HbA1c change, weight change and rate of hypoglycemia in randomized controlled trials comparing GLP-1 receptor agonist to premixed or prandial insulin.

\begin{tabular}{|c|c|c|c|c|c|c|}
\hline Clinical trial & $\begin{array}{l}\text { Background } \\
\text { therapy }\end{array}$ & $\begin{array}{l}\text { Study } \\
\text { duration }\end{array}$ & Treatment & $\begin{array}{l}\triangle \text { HbA1c during } \\
\text { study }\end{array}$ & $\begin{array}{l}\Delta \text { Weight }(\mathrm{kg}) \text { during } \\
\text { study }\end{array}$ & Rate of hypoglycemia \\
\hline Bergenstal et al. [75] & Met, SU & 24 weeks & $\begin{array}{l}\text { Exenatide } 5-10 \mu \mathrm{g} \text { BID } \\
\text { Premixed aspart 70/30 }\end{array}$ & $\begin{array}{c}-1.8 \\
\text { qD: }-2.3^{* * *} \\
\text { BID: }-2.8^{* * *}\end{array}$ & $\begin{array}{c}-1.9 \\
\text { qD: }+2.8 \\
\text { BID: }+4.1\end{array}$ & $\begin{array}{c}29 \% \\
56-61 \%\end{array}$ \\
\hline Gallwitz et al. [76] & Met & 26 weeks & $\begin{array}{l}\text { Exenatide } 5-10 \mu \mathrm{g} \text { BID } \\
\text { Premixed aspart } 70 / 30\end{array}$ & $\begin{array}{l}-1.0 \\
-1.1\end{array}$ & $\begin{array}{c}-4.1^{* * *} \\
+1.0\end{array}$ & $\begin{array}{c}8.0 \% \\
20.5 \%\end{array}$ \\
\hline Nauck et al. [77] & SU & 52 weeks & $\begin{array}{l}\text { Exenatide } 5-10 \mu \mathrm{g} \text { BID } \\
\text { Premixed aspart } 70.30\end{array}$ & $\begin{array}{l}-1.0 \\
-0.9\end{array}$ & $\begin{array}{l}-2.5^{* * *} \\
+2.9\end{array}$ & $\begin{array}{l}17 \%^{\mathrm{a}} \\
25 \%^{\mathrm{a}}\end{array}$ \\
\hline $\begin{array}{l}\text { Matthieu et al. [78] } \\
\text { (BEGIN VICTOZA ADD-ON) }\end{array}$ & iDeg, Met & 26 weeks & $\begin{array}{l}\text { Liraglutide } 0.6-1.8 \mathrm{mg} \mathrm{qD} \\
\text { Aspart qD }\end{array}$ & $\begin{array}{c}-0.7^{* *} \\
-0.4\end{array}$ & $\begin{array}{l}-2.8^{* * *} \\
+0.9\end{array}$ & $86 \%$ lower rate in liraglutide arm \\
\hline $\begin{array}{l}\text { Rosenstock et al. [79] } \\
\text { (HARMONY-6) }\end{array}$ & iGlar \pm Met \pm TZD & 36 weeks & $\begin{array}{l}\text { Albiglutide } 30-50 \mathrm{mg} \mathrm{qW} \\
\text { Lispro TID }\end{array}$ & $\begin{array}{l}-0.8 \\
-0.7\end{array}$ & $\begin{array}{l}-0.7^{* * *} \\
+0.8\end{array}$ & $\begin{array}{l}15.8 \% \\
29.9 \%\end{array}$ \\
\hline Diamant et al. [80] & Met, iGlar & 30 weeks & $\begin{array}{l}\text { Exenatide } 5-10 \mu \mathrm{g} \text { BID } \\
\text { Lispro TID }\end{array}$ & $\begin{array}{l}-1.1 \\
-1.1\end{array}$ & $\begin{array}{l}-2.5^{* * *} \\
+2.1\end{array}$ & $\begin{array}{l}15 \%\left(25 \%^{\mathrm{a}}\right) \\
34 \%\left(27 \%^{\mathrm{a}}\right)\end{array}$ \\
\hline $\begin{array}{l}\text { Xu et al. [81] } \\
\text { (CONFIDENCE) }\end{array}$ & None & 48 weeks & $\begin{array}{l}\text { Exenatide } 5-10 \mu \mathrm{g} \text { BID } \\
\text { Premixed lispro } 75 / 25\end{array}$ & $\begin{array}{l}-1.8 \\
-1.7\end{array}$ & $\begin{array}{l}-3.5^{* * *} \\
+1.0\end{array}$ & $\begin{array}{c}9.2 \% \\
13.0 \%\end{array}$ \\
\hline Rosenstock et al. [82] & $\mathrm{iGlar} \pm$ Met & 26 weeks & $\begin{array}{l}\text { Lixisenatide } 10 \rightarrow 20 \mu \mathrm{g} \text { qD } \\
\text { Glulisine TID }\end{array}$ & $\begin{array}{c}-0.6 \\
\text { TID: }-0.8\end{array}$ & $\begin{array}{c}-0.6^{* * *} \\
\text { TID: }+1.4\end{array}$ & $\begin{array}{l}35.9 \% \\
\text { TID: } 52.4 \%\end{array}$ \\
\hline
\end{tabular}

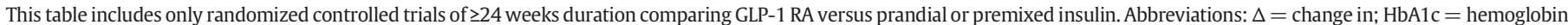

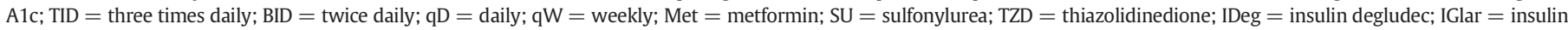
glargine. Statistical significance for HbA1c and weight changes: ${ }^{*}=\mathrm{p}$-value $<0.05,{ }^{* *}=\mathrm{p}$-value $<0.01$, $^{* * *}=\mathrm{p}$-value $<0.001$.

a Nocturnal hypoglycemia. 
Table 3

Comparison of glucagon-like 1 peptide receptor agonists and insulin.

\begin{tabular}{|c|c|c|}
\hline & Insulin & GLP-1 Receptor agonists \\
\hline $\begin{array}{l}\text { Glycemic } \\
\text { efficacy }\end{array}$ & Very effective & Very effective at full doses \\
\hline Weight & Weight gain & Weight loss \\
\hline Hypoglycemia & Yes & $\begin{array}{l}\text { No, but increases hypoglycemic } \\
\text { potential of insulin and insulin } \\
\text { secretagogues }\end{array}$ \\
\hline $\begin{array}{l}\text { Cardiovascular } \\
\text { benefit }\end{array}$ & Neutral & $\begin{array}{l}\text { Benefit in patients with pre-existing } \\
\text { atherosclerotic cardiovascular } \\
\text { disease }\end{array}$ \\
\hline Administration & $\begin{array}{l}1-4 \text { injections daily } \\
\text { Vial/syringe or pens }\end{array}$ & $\begin{array}{l}\text { Fewer injections; } 1-2 \text { times daily to } \\
\text { once weekly } \\
\text { Pen delivery systems }\end{array}$ \\
\hline Monitoring & $\begin{array}{l}\text { Glucose monitoring } \\
\text { essential }\end{array}$ & $\begin{array}{l}\text { Not necessary unless combined with } \\
\text { agents that can cause hypoglycemia }\end{array}$ \\
\hline $\begin{array}{l}\text { Other adverse } \\
\text { effects }\end{array}$ & $\begin{array}{l}\text { Rare injection site } \\
\text { reactions }\end{array}$ & $\begin{array}{l}\text { Gastrointestinal symptoms are } \\
\text { common } \\
\text { Within class variability in injection } \\
\text { site reactions }\end{array}$ \\
\hline $\begin{array}{l}\text { Safety } \\
\text { concerns }\end{array}$ & Hypoglycemia & $\begin{array}{l}\text { Gallstone events, but does not } \\
\text { translate to increase in } \\
\text { gallstone-associated pancreatitis }\end{array}$ \\
\hline Cost & $\begin{array}{l}\text { Cost of insulin analogues } \\
\text { has been increasing } \\
\text { dramatically }\end{array}$ & $\begin{array}{l}\text { Cost-effective for healthcare systems } \\
\text { Cost may be comparable to insulin } \\
\text { analogues, but more expensive than } \\
\text { human insulins } \\
\text { Remain cost prohibitive for some } \\
\text { patients }\end{array}$ \\
\hline
\end{tabular}

important when considering the negative impact of adiposity on glycemic control, and the vicious cycle generated when medication-induced weight gain drives further need for diabetes regimen intensification. Additionally, weight gain from insulin occurs not only at first initiation, but also cumulatively with escalating insulin doses over time [19]. Concurrent initiation of basal insulin and GLP-1 RA can offset weight gain due to insulin, and combination formulations have even demonstrated reductions in weight $[20,21]$.

Weight loss from GLP-1 RAs ranges from $1.5 \mathrm{~kg}$ to $6.0 \mathrm{~kg}$ over 30 weeks in clinical trials settings [7,22]. Evidence suggests that weight loss efficacy is greatest for semaglutide once weekly (mean $4.11 \mathrm{~kg}$ versus placebo), followed in descending order by liraglutide, dulaglutide, exenatide, albiglutide and lixisenatide $[7,22]$. In contrast, insulin leads to weight gain of 3 to $9 \mathrm{~kg}$ within the first year of initiation [19]. While obese patients are traditionally considered at highest risk of further weight gain and its consequences [19], real-world data suggests that patients with normal body mass index (BMI) experience more relative weight gain when starting insulin compared to obese patients [23]. This is noteworthy since there is a tendency to prescribe basal insulin over GLP-1 RA as a first injectable for patients with normal BMI [24], though this population appears to be at equal, or even higher, risk of insulin-associated weight gain and its subsequent consequences.

As with glycemic efficacy, it is important to consider how weight loss may differ in RCTs versus real-world settings. Evidence suggests that weight loss from GLP-1 RAs in real-world populations is similar to that observed in RCTs, although adherence is critical in this regard. In a recent study by Carls et al. [25], patients who were adherent to GLP-1 RA therapy experienced significantly greater weight loss $(4.30 \mathrm{~kg})$ than poorly-adherent patients $(1.88 \mathrm{~kg})$.

\subsubsection{Hypoglycemia}

Insulin and sulfonylureas place patients at considerable risk of hypoglycemia. In contrast to exogenous insulin (and insulin secretagogues), GLP-1 RAs increase endogenous insulin in a glucose-dependent manner. As a result, risk of hypoglycemia is low with GLP-1 RAs, although by lowering $\mathrm{HbA} 1 \mathrm{c}$, they amplify the hypoglycemic potential of insulin and sulfonylureas [5]. In the Dual Action of Liraglutide and Insulin Degludec in Type 2 Diabetes (DUAL) II trial [26], 413 patients on basal insulin and metformin ( \pm sulfonylurea or glinides) were randomized to once-daily insulin degludec/liraglutide + metformin or once-daily degludec + metformin in a blinded fashion. Doses of combination insulin degludec/ liraglutide and degludec alone were up-titrated according to a predefined algorithm (target fasting glucose $72-90 \mathrm{mg} / \mathrm{dL}$ ), and after 26 weeks the mean daily doses of degludec, alone or as part of combined insulin degludec/liraglutide, were the same in both arms (45 units, p = NS). Interestingly, the incidence of hypoglycemia was comparable between the treatment arms (insulin degludec/liraglutide $24 \%$ versus degludec $25 \%$ ) despite a significantly lower mean HbA1c in the insulin degludec/ liraglutide arm [26]. Therefore, the equivalent glucose-lowering action of GLP-1 RAs coupled with an overall lower risk of hypoglycemia render them desirable alternatives to insulin. There is no significant difference in the risk of hypoglycemia across GLP-1 RAs [7].

While priorities regarding weight management may vary on a caseby-case basis, minimizing hypoglycemia should always be a priority for patients and providers. Individuals at especially high-risk of hypoglycemia include elderly patients, those with hypoglycemic unawareness and/or impaired renal function [27]. Furthermore, avoidance of hypoglycemia is of utmost importance for individuals in high-risk occupations, such as truck drivers, pilots, safety officers (police, firefighters), and anyone operating heavy machinery at work. In such cases it is preferable to exhaust all (feasible) glucose-lowering options with low hypoglycemic potential prior to advancing to sulfonylureas or insulin therapy. In order to minimize hypoglycemia while not compromising glycemic control, GLP-1 RAs could also be considered in those who are fasting for long stretches of time, such as occurs annually for patients observing Ramadan [28].

\subsubsection{Cardiovascular outcomes trials}

A major update to the ADA-EASD consensus guidelines is the recommendation to consider a history of atherosclerotic cardiovascular disease, heart failure or chronic kidney disease when deciding on preferred approaches to glucose-lowering therapy [3]. This is based on new evidence suggesting that sodium-glucose cotransporter 2 (SGLT2) inhibitors and GLP-1 RAs improve cardiovascular outcomes in patients with pre-existing cardiovascular disease (CVD) $[3,29]$. As discussed by Rizzo et al. in this issue, except for lixisenatide the GLP-1 RAs have demonstrated broad-based benefits on atherosclerotic cardiovascular disease outcomes and/or mortality in patients with preexisting CVD. Until recently, dulaglutide was the only marketed GLP-1 RA without cardiovascular outcomes data. However, the Researching cardiovascular Events with a Weekly INcretin in Diabetes (REWIND) trial results were released in June 2019 [30], and dulaglutide was found to reduce cardiovascular events compared to placebo; driven primarily by reduction in non-fatal stroke. In contrast to previous cardiovascular outcomes trials of GLP-1 RAs, REWIND had the lowest proportion of participants with pre-existing CVD (31\%), the lowest baseline HbA1c (7.3\%), the highest female representation (46\%) and the longest median follow-up time (5.4 years) [29,30]. The large proportion of patients without established CVD in REWIND suggests a potential role for GLP-1 RAs in primary prevention of CVD in those with diabetes and cardiovascular risk factors (at least two of: tobacco abuse, dyslipidemia, hypertension or abdominal adiposity) [30]. Additionally, as the REWIND trial had no lower limit for HbA1c as an eligibility criterion, and as there was no evidence of heterogeneity based on HbA1c at entry, this suggests that guidelines regarding cardiovascular protection may need to be generalized to adding dulaglutide, or another GLP-1 RA with proven efficacy for CV event reduction, independent of whether the patient is at glycemic goal [30].

Notably, results from the phase 3a Peptide Innovation for Early Diabetes Treatment 6 (PIONEER 6) trial were also released in June 2019 [31], and the primary objective of confirming noninferiority of oral semaglutide to placebo for cardiovascular safety was achieved. Furthermore, a significant relative reduction in risk of cardiovascular death and all-cause mortality were observed with oral semaglutide compared to placebo [31]. 
While insulins are safe to use in patients with pre-existing CVD they lack evidence for cardiovascular benefit [32,33]; thus GLP-1 RAs should be preferred in this scenario [3]. If insulin is necessary to achieve glycemic control in patients with CVD, ensuring room for a GLP-1 RA in the regimen is still desirable for cardiovascular benefit [34]. It remains unclear whether cardiovascular protection is a drug-class effect or whether differences among GLP-1 RAs account for differential effects on CVD in trials. This should be discussed with patients when deciding on intensification to GLP-1 RA therapy, as the evidence for cardiovascular benefit in patients with established CVD is variable and there are other domains that could drive decision-making in selecting an agent from within the class.

GLP-1 RAs have also demonstrated reductions in the relative risk of composite renal outcomes compared to placebo; this effect is primarily driven by reduction in macroalbuminuria $[29,30]$. Further studies will be needed to better understand this potential benefit of GLP-1 RAs, although evidence suggests these agents are at least safe to use from a renal perspective.

\subsubsection{Administration of injectable therapies}

Adherence and persistence to therapies are largely influenced by ease of medication delivery, frequency of dosing, and other aspects of administration which may add complexity to the daily routine [35,36]. For instance, non-adherence is greater with injectables than pills, since injectables are more challenging to administer and can be unpleasant for the patient. [37] Likewise, adherence is better for insulin pens than insulin administered by vial and syringe [36,38]. Hence, when comparing ease of use between medication classes, differences will be wider between GLP-1 RAs and insulin administered by vial and syringe, versus GLP-1 RAs and insulin delivered via pen; the latter comparison is most commonly assessed in RCTs.

Currently GLP-1 RAs are available in pen form, however delivery systems vary in complexity. For instance, the initial extended-release exenatide pen was considerably more complex to use than other GLP1 RAs as it required reconstitution, which relied on the patient firmly tapping the pen on their palm 80 or more times prior to use. In contrast, liraglutide and semaglutide employ multiuse pens which simply require the patient to dial to the correct dose, remove the needle cap and inject the medication. The difference in complexity between these two delivery systems may have accounted for the better adherence observed with liraglutide versus exenatide in real-world settings [4]. In the U.S., a simpler single-use autoinjector device for extended-release exenatide was developed and became available in 2018; it still requires $15 \mathrm{~s}$ of reconstitution, but is otherwise much easier to use. Dulaglutide is administered once weekly as a single use pen and only requires removal of the needle cap and unlocking of the device before administration. Doses are preset in the exenatide autoinjector and dulaglutide pens, thus no dose adjustments are needed. Furthermore, these two devices are the only ones to hide the needle tip, which may be important for patients whose fear of needles poses a barrier to adherence.

Efficacy of glucose-lowering agents relies heavily on adherence, which is inversely related to number of daily injections [39]. With the exception of twice-daily exenatide, all other GLP-1 RAs allow for the same or lower number of injections compared to basal insulin (typically once daily). Extended-release exenatide, dulaglutide and semaglutide are given weekly, which improves adherence in real-world settings compared to daily injections, and also aligns more closely with patient preferences for a once-weekly, single use pen (exenatide, dulaglutide), versus a daily multiuse pen [4].

Finally, initiation of insulin calls for considerable change to selfefficacy behaviors, such as consistency in meal taking or carbohydrate counting, and it requires regular self-monitoring of blood glucose for insulin titration and screening for hypoglycemia. The burden of glucose self-monitoring can contribute substantially to diabetes distress in patients initiating insulin. [40] Despite their contribution to nonadherence [41], patient-reported outcomes such as distress and depression are often not measured in trials. Since GLP-1 RAs carry minimal risk of hypoglycemia, patients do not need to monitor glucose except when co-administered with an agent with hypoglycemic potential. As such, choosing GLP-1 RAs as first injectable therapy relieves patients of a large self-management burden which may have otherwise contributed to non-adherence and patient disengagement. In the absence of background medications that can cause hypoglycemia, GLP-1 RAs are also easier to prescribe from a provider perspective since they can be safely started without the need for glycemic trends data.

Real-world persistence to GLP-1 RAs varies by study, but is in the range of $47 \%$ to $80 \%$, and tends to be higher for dulaglutide than for exenatide or liraglutide $[4,42]$. While adherence and persistence levels under $80 \%$ may be discouraging for providers, this should not argue against prescribing GLP-1 RAs, since adherence to insulin also varies widely, from $43 \%$ to $86 \%$ [38]. Therefore, focus should instead be placed on individual patient factors that may influence the selection of one injectable over another, as well as patient counseling and shared decisionmaking to promote adherence.

\subsubsection{Safety and tolerability}

Gastrointestinal symptoms are the most common side effects of GLP-1 RA therapy, and occur in as many as $50 \%$ of patients $[7,43]$. They are also the leading cause of GLP-1 RA discontinuation [42]. Among commonly used GLP-1 RAs, semaglutide has the highest rates of nausea and vomiting, followed by dulaglutide, liraglutide, exenatide twice-daily, and extended-release exenatide. This pattern is similar for diarrhea, though liraglutide is slightly more likely to cause diarrhea than dulaglutide, and both formulations of exenatide are least likely to do this $[7,44,45]$. Interestingly, in the DUAL II trial [26] comparing combination insulin degludec/liraglutide versus insulin degludec alone, patients were blinded and gastrointestinal adverse events were strikingly lower with combined insulin degludec/liraglutide than reported with GLP-1 RAs in other trials [46], which was attributed to starting at low doses with slow up-titrations. Given the high likelihood of gastrointestinal symptoms, it is important to include this in discussions with the patient prior to initiation. Providers should also initiate GLP-1 RAs at lowest doses first and ensure that titration beyond maximum tolerated dose does not occur, or that decreasing to a lower tolerable dose be accomplished immediately.

Patients who experience injection site reactions are also highly likely to discontinue drug therapy [5]. Overall these reactions are uncommon with GLP-1 RAs, but not as low as the $\leq 0.1 \%$ incidence with insulin analogues [47]. Extended-release exenatide has the highest risk of injection site reactions [7], and in the SUSTAIN 3 trial, this occurred in $22 \%$ of participants, versus $1.2 \%$ with semaglutide [45].

From a safety standpoint, a major advantage to GLP-1 RAs over insulin is reduced risk of hypoglycemia, as previously discussed. However, safety concerns have been raised regarding risk of medullary thyroid cancer, as well as pancreatic and gallbladder events. Overall, GLP-1RA increase serum levels of lipase and amylase though this seems unrelated to the risk of pancreatitis [48]. In blinded long-term cardiovascular outcome trials, no significant differences were seen in pancreatitis, pancreatic cancer, or medullary thyroid cancer between GLP-1 RA and placebo [49]. However, evidence suggests that GLP-1 RAs do increase risk of cholelithiasis $[48,50,51]$, though this does not translate to increase in gallstone-associated acute pancreatitis. Thus, based on recent evidence, the consensus is that while GLP-1 RAs may increase risk of gallbladder events, they do not appear to elevate risk of pancreatitis, pancreatic cancer, or medullary thyroid cancer, at least in the intermediate-term follow-up of the trials ( $<5$ years) [48-51].

A final safety consideration worth noting is the higher risk of retinopathy complications observed with semaglutide in the SUSTAIN 6 trial [52]. This occurred predominantly in patients with rapid improvement in glycemic control during the study, a recognized phenomenon of medication intensification, and one that was even observed with use of insulin in the Diabetes Control and Complications Trial (DCCT) [53]. As 
such, the significance of this finding as it pertains to the GLP-1 RA versus insulin comparison is unclear, and long-term studies on retinopathy outcomes are needed to shed further light on this.

\subsubsection{Cost considerations}

Cost has presented perhaps the greatest limitation to widespread use of GLP-1 RAs. Cost-effectiveness studies incorporate cost of medications, as well as other healthcare-related expenditures and quality of life. Such studies suggest that medication costs associated with GLP-1 RAs are offset by reduction in other healthcare-related expenses, rendering them cost-effective [4,54]. Notably, GLP-1 RAs also negate the need for glucose self-monitoring, whereas insulin will always be associated with this added expense. Despite cost-effectiveness to healthcare systems, many patients are unable to afford GLP-1 RAs. When comparing patient-level costs, it is important to consider that GLP-1 RAs can replace $50-80$ units of insulin with similar glycemic efficacy $[10,55]$. This daily cost of insulin is not trivial, particularly for insulin analogues whose cost has risen dramatically over the past several years [56-58]. Therefore, for patients with an average HbA1c of $8-8.5 \%$ (as in RCTs), cost parity is arguably similar between GLP-1 RA and insulin analogues in many cases; though data are mixed $[59,60]$. Human insulins are cheaper and should compare favorably with respect to the cost of GLP-1 RAs, though direct comparisons in trials have not been performed.

\section{Conclusion}

Recent guidelines recommend GLP-1 RAs as initial injectable therapy over basal insulin in most cases, based on similar or higher glycemic efficacy, weight reduction, lower risk of hypoglycemia, and cardiovascular benefit in those with atherosclerotic CVD. Real-world evidence suggests that adherence is suboptimal for both GLP-1 RAs and insulin, the former driven by adverse gastrointestinal symptoms which are common. Assuming adherence, GLP-1 RAs offer numerous benefits beyond insulin which have been discussed in this review, including lower selfmanagement burden and the possibility of fewer injections. However with this shift in recommendations it is important for providers to engage patients in care discussions and to be mindful of individual factors which may impact the success of therapy, such as safety, tolerability and cost.

\section{Declaration of Competing Interest}

A.S.A. is conducting research with Novo Nordisk, but has no other conflicts of interest to report. J.B.B.'s contracted consulting fees are paid to the University of North Carolina by Adocia, AstraZeneca, Dance Biopharm, Dexcom, Elcelyx Therapeutics, Eli Lilly, Fractyl, GI Dynamics, Intarcia Therapeutics, Lexicon, MannKind, Metavention, NovaTarg, Novo Nordisk, Orexigen, PhaseBio, Sanofi, Senseonics, Shenzhen HighTide, Takeda, vTv Therapeutics, and Zafgen; he reports grant support from AstraZeneca, Eli Lilly, GI Dynamics, GlaxoSmithKline, Intarcia Therapeutics, Johnson \& Johnson, Lexicon, Medtronic, Novo Nordisk, Orexigen, Sanofi, Scion NeuroStim, Takeda, Theracos and vTv Therapeutics; he is a consultant to Cirius Therapeutics Inc., CSL Behring, Neurimmune AG and Whole Biome; he holds stock options in Mellitus Health, PhaseBio and Stability Health.

\section{Acknowledgements}

Research reported in this publication was supported by the National Institutes of Health under Award Number T32DK007012 (A.S.A) and UL1TR002489 (JBB).

\section{Author contributions}

A.S.A. and J.B.B. conceived of and designed the structure of the review. A.S.A. collected data and drafted the manuscript. J.B.B. reviewed and provided edits to the text of the manuscript.

\section{References}

[1] Ringborg A, Lindgren P, Yin DD, Martinell M, Stalhammar J. Time to insulin treatment and factors associated with insulin prescription in Swedish patients with type 2 diabetes. Diabetes Metab Jun 2010;36:198-203.

[2] Machado-Alba JE, Machado-Duque ME, Moreno-Gutierrez PA. Time to and factors associated with insulin initiation in patients with type 2 diabetes mellitus. Diabetes Res Clin Pract Mar 2015;107:332-7.

[3] Davies MJ, D'Alessio DA, Fradkin J, Kernan WN, Mathieu C, Mingrone G, et al. Management of hyperglycemia in type 2 diabetes, 2018. A consensus report by the American Diabetes Association (ADA) and the European Association for the Study of Diabetes (EASD). Diabetes Care Dec 2018;41:2669-701.

[4] Guerci B, Charbonnel B, Gourdy P, Hadjadj S, Hanaire H, Marre M, et al. Efficacy and adherence of glucagon-like peptide-1 receptor agonist treatment in patients with type 2 diabetes mellitus in real-life settings. Diabetes Metab Jan 21 2019:1-8 (Epub ahead of print).

[5] Li Z, Zhang Y, Quan X, Yang Z, Zeng X, Ji L, et al. Efficacy and acceptability of glycemic control of glucagon-like peptide- 1 receptor agonists among type 2 diabetes: a systematic review and network meta-analysis. PLoS One 2016;11:e0154206.

[6] Drucker DJ, Nauck MA. The incretin system: glucagon-like peptide-1 receptor agonists and dipeptidyl peptidase-4 inhibitors in type 2 diabetes. Lancet Nov 11 2006; 368:1696-705.

[7] Htike ZZ, Zaccardi F, Papamargaritis D, Webb DR, Khunti K, Davies MJ. Efficacy and safety of glucagon-like peptide- 1 receptor agonists in type 2 diabetes: a systematic review and mixed-treatment comparison analysis. Diabetes Obes Metab Apr 2017; 19:524-36.

[8] Levin PA, Nguyen H, Wittbrodt ET, Kim SC. Glucagon-like peptide-1 receptor agonists: a systematic review of comparative effectiveness research. Diabetes Metab Syndr Obes 2017;10:123-39.

[9] Buse JB, Peters A, Russell-Jones D, Furber S, Donsmark M, Han J, et al. Is insulin the most effective injectable antihyperglycaemic therapy? Diabetes Obes Metab Feb 2015; $17: 145-51$

[10] Aroda VR, Bain SC, Cariou B, Piletic M, Rose L, Axelsen M, et al. Efficacy and safety of once-weekly semaglutide versus once-daily insulin glargine as add-on to metformin (with or without sulfonylureas) in insulin-naive patients with type 2 diabetes (SUSTAIN 4): a randomised, open-label, parallel-group, multicentre, multinational, phase 3a trial. Lancet Diabetes Endocrinol May 2017:5:355-66.

[11] Minambres I, Perez A. Is there a justification for classifying GLP-1 receptor agonists as basal and prandial? Diabetol Metab Syndr 2017;9:6.

[12] Buse JB, Rosenstock J, Sesti G, Schmidt WE, Montanya E, Brett JH, et al. Liraglutide once a day versus exenatide twice a day for type 2 diabetes: a 26-week randomised, parallel-group, multinational, open-label trial (LEAD-6). Lancet Jul 4 2009;374: 39-47.

[13] Novo Nordisk. Insulin degludec/liraglutide (IDegLira) May 24, 2016, 3/10/19: 1-33 Available: https://www.fda.gov/downloads/AdvisoryCommittees/ CommitteesMeetingMaterials/Drugs/

EndocrinologicandMetabolicDrugsAdvisoryCommittee/UCM502076.pdf.

[14] Sanofi. Lixisenatide and iGlarLixi. Available: https://www.fda.gov/downloads/ advisorycommittees/committeesmeetingmaterials/drugs/ endocrinologicandmetabolicdrugsadvisorycommittee/ucm502559.pdf; May 25, 2016, 3/10/2019.

[15] Maiorino MI, Chiodini P, Bellastella G, Scappaticcio L, Longo M, Esposito K, et al. Free and fixed-ratio combinations of basal insulin and GLP-1 receptor agonists versus basal insulin intensification in type 2 diabetes: a systematic review and metaanalysis of randomized controlled trials. Diabetes Obes Metab Sep 2018;20: 2309-13.

[16] Carls GS, Tuttle E, Tan RD, Huynh J, Yee J, Edelman SV, et al. Understanding the gap between efficacy in randomized controlled trials and effectiveness in real-world use of GLP-1 RA and DPP-4 therapies in patients with type 2 diabetes. Diabetes Care Nov 2017;40:1469-78.

[17] D'Alessio D, Haring HU, Charbonnel B, de Pablos-Velasco P, Candelas C, Dain MP, et al. Comparison of insulin glargine and liraglutide added to oral agents in patients with poorly controlled type 2 diabetes. Diabetes Obes Metab Feb 2015;17:170-8.

[18] Durden E, Liang M, Fowler R, Panton UH, Mocevic E. The effect of early response to GLP-1 RA therapy on long-term adherence and persistence among type 2 diabetes patients in the United States. J Manag Care Spec Pharm Mar 21 2019:1-10.

[19] Brown A, Guess N, Dornhorst A, Taheri S, Frost G. Insulin-associated weight gain in obese type 2 diabetes mellitus patients: what can be done? Diabetes Obes Metab Dec 2017; 19:1655-68.

[20] Lingvay I, Perez Manghi F, Garcia-Hernandez P, Norwood P, Lehmann L, TarpJohansen MJ, et al. Effect of insulin glargine up-titration vs insulin degludec/ liraglutide on glycated hemoglobin levels in patients with uncontrolled type 2 diabetes: the DUAL V randomized clinical trial. JAMA Mar 1 2016;315:898-907.

[21] Aroda VR, Rosenstock J, Wysham C, Unger J, Bellido D, Gonzalez-Galvez G, et al. Efficacy and safety of LixiLan, a titratable fixed-ratio combination of insulin glargine plus lixisenatide in type 2 diabetes inadequately controlled on basal insulin and metformin: the LixiLan-L randomized trial. Diabetes Care Nov 2016;39:1972-80.

[22] Andreadis P, Karagiannis T, Malandris K, Avgerinos I, Liakos A, Manolopoulos A, et al. Semaglutide for type 2 diabetes mellitus: a systematic review and meta-analysis. Diabetes Obes Metab Sep 2018;20:2255-63.

[23] Paul SK, Shaw JE, Montvida O, Klein K. Weight gain in insulin-treated patients by body mass index category at treatment initiation: new evidence from real-world data in patients with type 2 diabetes. Diabetes Obes Metab Dec 2016;18:1244-52.

[24] Yu M, Mody R, Lando LF, Shui A, Kallenbach L, Slipski L, et al. Characteristics associated with the choice of first injectable therapy among US patients with type 2 diabetes. Clin Ther Dec 2017;39:2399-408. 
[25] Carls GS, Tan R, Zhu JY, Tuttle E, Yee J, Edelman SV, et al. Real-world weight change among patients treated with glucagon-like peptide- 1 receptor agonist, dipeptidyl peptidase- 4 inhibitor and sulfonylureas for type 2 diabetes and the influence of medication adherence. Obes Sci Pract Sep 2017;3:342-51.

[26] Buse JB, Vilsboll T, Thurman J, Blevins TC, Langbakke IH, Bottcher SG, et al. Contribution of liraglutide in the fixed-ratio combination of insulin degludec and liraglutide (IDegLira). Diabetes Care Nov 2014;37:2926-33.

[27] Bloomfield HE, Greer N, Newman D, MacDonald R, Carlyle M, Fitzgerald P, et al. Predictors and consequences of severe hypoglycemia in adults with diabetes - a systematic review of the evidence, ed Washington (DC); 2012.

[28] Gray LJ, Dales J, Brady EM, Khunti K, Hanif W, Davies MJ. Safety and effectiveness of non-insulin glucose-lowering agents in the treatment of people with type 2 diabetes who observe Ramadan: a systematic review and meta-analysis. Diabetes Obes Metab Jul 2015;17:639-48.

[29] Zelniker TA, Wiviott SD, Raz I, Im K, Goodrich EL, Furtado RHM, et al. Comparison of the effects of glucagon-like peptide receptor agonists and sodium-glucose cotransporter 2 inhibitors for prevention of major adverse cardiovascular and renal outcomes in type 2 diabetes mellitus. Circulation Apr 23 2019;139:2022-31.

[30] Gerstein HC, Colhoun HM, Dagenais GR, Diaz R, Lakshmanan M, Pais P, et al. Dulaglutide and cardiovascular outcomes in type 2 diabetes (REWIND): a doubleblind, randomised placebo-controlled trial. Lancet Jun 72019 (Epub ahead of print) https://www.ncbi.nlm.nih.gov/pubmed/31189511; May 25, 2016, 3/10/2019.

[31] Husain M, Birkenfeld AL, Donsmark M, Dungan K, Eliaschewitz FG, Franco DR, et al. Oral semaglutide and cardiovascular outcomes in patients with type 2 diabetes. $\mathrm{N}$ Engl J Med Jun 112019 (Epub ahead of print) https://www.ncbi.nlm.nih.gov/ pubmed/31185157; May 25, 2016, 3/10/2019.

[32] Investigators OT, Gerstein HC, Bosch J, Dagenais GR, Diaz R, Jung H, et al. Basal insulin and cardiovascular and other outcomes in dysglycemia. N Engl J Med Jul 26 2012; 367:319-28.

[33] Marso SP, McGuire DK, Zinman B, Poulter NR, Emerson SS, Pieber TR, et al. Efficacy and safety of degludec versus glargine in type 2 diabetes. N Engl J Med Aug 24 2017;377:723-32.

[34] Vilsboll T, Blevins TC, Jodar E, Poulter N, Tentolouris N, Ross Agner BF, et al. Fixedratio combination of insulin degludec and liraglutide (IDegLira) improves cardiovascular risk markers in patients with type 2 diabetes uncontrolled on basal insulin. Diabetes Obes Metab Feb 20 2019;21:1506-12.

[35] de Vries ST, Keers JC, Visser R, de Zeeuw D, Haaijer-Ruskamp FM, Voorham J, et al. Medication beliefs, treatment complexity, and non-adherence to different drug classes in patients with type 2 diabetes. J Psychosom Res Feb 2014;76:134-8.

[36] Polonsky WH, Henry RR. Poor medication adherence in type 2 diabetes: recognizing the scope of the problem and its key contributors. Patient Prefer Adherence 2016;10: 1299-307.

[37] Garcia-Perez LE, Alvarez M, Dilla T, Gil-Guillen V, Orozco-Beltran D. Adherence to therapies in patients with type 2 diabetes. Diabetes Ther Dec 2013;4:175-94.

[38] Davies MJ, Gagliardino JJ, Gray LJ, Khunti K, Mohan V, Hughes R. Real-world factors affecting adherence to insulin therapy in patients with Type 1 or Type 2 diabetes mellitus: a systematic review. Diabet Med May 2013;30:512-24.

[39] Peyrot M, Rubin RR, Kruger DF, Travis LB. Correlates of insulin injection omission. Diabetes Care Feb 2010;33:240-5.

[40] Tanenbaum ML, Kane NS, Kenowitz J, Gonzalez JS. Diabetes distress from the patient's perspective: qualitative themes and treatment regimen differences among adults with type 2 diabetes. J Diabetes Complicat Aug 2016;30:1060-8.

[41] Halepian L, Saleh MB, Hallit S, Khabbaz LR. Adherence to insulin, emotional distress, and trust in physician among patients with diabetes: a cross-sectional study. Diabetes Ther Apr 2018;9:713-26.

[42] Sikirica MV, Martin AA, Wood R, Leith A, Piercy J, Higgins V. Reasons for discontinuation of GLP1 receptor agonists: data from a real-world cross-sectional survey of physicians and their patients with type 2 diabetes. Diabetes Metab Syndr Obes 2017;10:403-12.

[43] Filippatos TD, Panagiotopoulou TV, Elisaf MS. Adverse effects of GLP-1 receptor agonists. Rev Diabet Stud Fall-Winter 2014;11:202-30.

[44] Nauck MA, Petrie JR, Sesti G, Mannucci E, Courreges JP, Lindegaard ML, et al. A phase 2 , randomized, dose-finding study of the novel once-weekly human GLP-1 analog, semaglutide, compared with placebo and open-label liraglutide in patients with type 2 diabetes. Diabetes Care Feb 2016;39:231-41.

[45] Ahmann AJ, Capehorn M, Charpentier G, Dotta F, Henkel E, Lingvay I, et al. Efficacy and safety of once-weekly semaglutide versus exenatide ER in subjects with type 2 diabetes (SUSTAIN 3): a 56-week, open-label, randomized clinical trial. Diabetes Care Feb 2018;41:258-66.

[46] Drab SR. Glucagon-like peptide- 1 receptor agonists for type 2 diabetes: a clinical update of safety and efficacy. Curr Diabetes Rev 2016;12:403-13.

[47] Bzowyckyj AS, Stahnke AM. Hypersensitivity reactions to human insulin analogs in insulin-naive patients: a systematic review. Ther Adv Endocrinol Metab Feb 2018; 9:53-65.

[48] Steinberg WM, Buse JB, Ghorbani MLM, Orsted DD, Nauck MA, Committee LS, et al. Amylase, lipase, and acute pancreatitis in people with type 2 diabetes treated with liraglutide: results from the LEADER randomized trial. Diabetes Care Jul 2017;40: 966-72.

[49] Bethel MA, Patel RA, Merrill P, Lokhnygina Y, Buse JB, Mentz RJ, et al. Cardiovascular outcomes with glucagon-like peptide-1 receptor agonists in patients with type 2 diabetes: a meta-analysis. Lancet Diabetes Endocrinol Feb 2018;6: 105-13.

[50] Monami M, Nreu B, Scatena A, Cresci B, Andreozzi F, Sesti G, et al. Safety issues with glucagon-like peptide-1 receptor agonists (pancreatitis, pancreatic cancer and cholelithiasis): data from randomized controlled trials. Diabetes Obes Metab Sep 2017;19:1233-41.
[51] Storgaard H, Cold F, Gluud LL, Vilsboll T, Knop FK. Glucagon-like peptide-1 receptor agonists and risk of acute pancreatitis in patients with type 2 diabetes. Diabetes Obes Metab Jun 2017;19:906-8.

[52] Marso SP, Bain SC, Consoli A, Eliaschewitz FG, Jodar E, Leiter LA, et al. Semaglutide and cardiovascular outcomes in patients with type 2 diabetes. N Engl J Med Nov 10 2016;375:1834-44.

[53] Early worsening of diabetic retinopathy in the Diabetes Control and Complications Trial, Arch Ophthalmol Jul 1998;116:874-86.

[54] Hong D, Si L, Jiang M, Shao H, Ming WK, Zhao Y, et al. Cost effectiveness of sodiumglucose cotransporter-2 (SGLT2) inhibitors, glucagon-like peptide-1 (GLP-1) receptor agonists, and dipeptidyl peptidase-4 (DPP-4) inhibitors: a systematic review. Pharmacoeconomics Mar 11 2019;37:777-818.

[55] Castellana M, Cignarelli A, Brescia F, Laviola L, Giorgino F. GLP-1 receptor agonist added to insulin versus basal-plus or basal-bolus insulin therapy in type 2 diabetes: a systematic review and meta-analysis. Diabetes Metab Res Rev Jan 2019;35:e3082.

[56] Hua X, Carvalho N, Tew M, Huang ES, Herman WH, Clarke P. Expenditures and prices of antihyperglycemic medications in the United States: 2002-2013. JAMA Apr 5 2016;315:1400-2.

[57] Luo J, Avorn J, Kesselheim AS. Trends in Medicaid reimbursements for insulin from 1991 through 2014. JAMA Intern Med Oct 2015;175:1681-6.

[58] Cefalu WT, Dawes DE, Gavlak G, Goldman D, Herman WH, Van Nuys K, et al. Insulin Access and Affordability Working Group: conclusions and recommendations. Diabetes Care Jun 2018;41:1299-311.

[59] Samyshkin Y, Guillermin AL, Best JH, Brunell SC, Lloyd A. Long-term cost-utility analysis of exenatide once weekly versus insulin glargine for the treatment of type $2 \mathrm{di}$ abetes patients in the US. J Med Econ 2012;15(Suppl. 2):6-13.

[60] Wittbrodt E, Kong AM, Moore-Schiltz L, Juneau P. All-cause and diabetes-related healthcare costs among US adults with type 2 diabetes initiating exenatide once weekly or insulin glargine. Diabetes Obes Metab Mar 2018;20:672-80.

[61] Davies MJ, Donnelly R, Barnett AH, Jones S, Nicolay C, Kilcoyne A. Exenatide compared with long-acting insulin to achieve glycaemic control with minimal weight gain in patients with type 2 diabetes: results of the Helping Evaluate Exenatide in patients with diabetes compared with Long-Acting insulin (HEELA) study. Diabetes Obes Metab Dec 2009;11:1153-62.

[62] Diamant M, Van Gaal L, Guerci B, Stranks S, Han J, Malloy J, et al. Exenatide once weekly versus insulin glargine for type 2 diabetes (DURATION-3): 3-year results of an open-label randomised trial. Lancet Diabetes Endocrinol Jun 2014;2:464-73.

[63] Diamant M, Van Gaal L, Stranks S, Guerci B, MacConell L, Haber H, et al. Safety and efficacy of once-weekly exenatide compared with insulin glargine titrated to target in patients with type 2 diabetes over 84 weeks. Diabetes Care Apr 2012;35:683-9.

[64] Diamant M, Van Gaal L, Stranks S, Northrup J, Cao D, Taylor K, et al. Once weekly exenatide compared with insulin glargine titrated to target in patients with type 2 diabetes (DURATION-3): an open-label randomised trial. Lancet Jun 26 2010;375: 2234-43.

[65] Heine RJ, Van Gaal LF, Johns D, Mihm MJ, Widel MH, Brodows RG, et al. Exenatide versus insulin glargine in patients with suboptimally controlled type 2 diabetes: a randomized trial. Ann Intern Med Oct 18 2005;143:559-69.

[66] Inagaki N, Atsumi Y, Oura T, Saito H, Imaoka T. Efficacy and safety profile of exenatide once weekly compared with insulin once daily in Japanese patients with type 2 diabetes treated with oral antidiabetes drug(s): results from a 26week, randomized, open-label, parallel-group, multicenter, noninferiority study. Clin Ther Sep 2012;34(e1):1892-908.

[67] Araki E, Inagaki N, Tanizawa Y, Oura T, Takeuchi M, Imaoka T. Efficacy and safety of once-weekly dulaglutide in combination with sulphonylurea and/or biguanide compared with once-daily insulin glargine in Japanese patients with type 2 diabetes: a randomized, open-label, phase III, non-inferiority study. Diabetes Obes Metab Oct 2015; 17:994-1002.

[68] Blonde L, Jendle J, Gross J, Woo V, Jiang H, Fahrbach JL, et al. Once-weekly dulaglutide versus bedtime insulin glargine, both in combination with prandial insulin lispro, in patients with type 2 diabetes (AWARD-4): a randomised, open-label, phase 3 , noninferiority study. Lancet May 23 2015;385:2057-66.

[69] Giorgino F, Benroubi M, Sun JH, Zimmermann AG, Pechtner V. Efficacy and safety of once-weekly dulaglutide versus insulin glargine in patients with type 2 diabetes on metformin and glimepiride (AWARD-2). Diabetes Care Dec 2015;38:2241-9.

[70] Russell-Jones D, Vaag A, Schmitz O, Sethi BK, Lalic N, Antic S, et al. Liraglutide vs insulin glargine and placebo in combination with metformin and sulfonylurea therapy in type 2 diabetes mellitus (LEAD-5 met $+\mathrm{SU}$ ): a randomised controlled trial. Diabetologia Oct 2009;52:2046-55.

[71] Davies M, Heller S, Sreenan S, Sapin H, Adetunji O, Tahbaz A, et al. Once-weekly exenatide versus once- or twice-daily insulin detemir: randomized, open-label, clinical trial of efficacy and safety in patients with type 2 diabetes treated with metformin alone or in combination with sulfonylureas. Diabetes Care May 2013;36: 1368-76.

[72] Gough SC, Bode B, Woo V, Rodbard HW, Linjawi S, Poulsen P, et al. Efficacy and safety of a fixed-ratio combination of insulin degludec and liraglutide (IDegLira) compared with its components given alone: results of a phase 3, open-label, randomised, 26-week, treat-to-target trial in insulin-naive patients with type 2 diabetes. Lancet Diabetes Endocrinol Nov 2014;2:885-93.

[73] Gough SC, Bode BW, Woo VC, Rodbard HW, Linjawi S, Zacho M, et al. One-year efficacy and safety of a fixed combination of insulin degludec and liraglutide in patients with type 2 diabetes: results of a 26 -week extension to a 26-week main trial. Diabetes Obes Metab Oct 2015;17:965-73.

[74] Weissman PN, Carr MC, Ye J, Cirkel DT, Stewart M, Perry C, et al. HARMONY 4: randomised clinical trial comparing once-weekly albiglutide and insulin glargine in patients with type 2 diabetes inadequately controlled with metformin with or without sulfonylurea. Diabetologia Dec 2014;57:2475-84. 
[75] Bergenstal R, Lewin A, Bailey T, Chang D, Gylvin T, Roberts V, et al. Efficacy and safety of biphasic insulin aspart 70/30 versus exenatide in subjects with type 2 diabetes failing to achieve glycemic control with metformin and a sulfonylurea. Curr Med Res Opin Jan 2009;25:65-75.

[76] Gallwitz B, Bohmer M, Segiet T, Molle A, Milek K, Becker B, et al. Exenatide twice daily versus premixed insulin aspart 70/30 in metformin-treated patients with type 2 diabetes: a randomized 26-week study on glycemic control and hypoglycemia. Diabetes Care Mar 2011;34:604-6.

[77] Nauck MA, Duran S, Kim D, Johns D, Northrup J, Festa A, et al. A comparison of twicedaily exenatide and biphasic insulin aspart in patients with type 2 diabetes who were suboptimally controlled with sulfonylurea and metformin: a non-inferiority study. Diabetologia Feb 2007;50:259-67.

[78] Mathieu C, Rodbard HW, Cariou B, Handelsman Y, Philis-Tsimikas A, Ocampo Francisco AM, et al. A comparison of adding liraglutide versus a single daily dose of insulin aspart to insulin degludec in subjects with type 2 diabetes (BEGIN: VICTOZA ADD-ON). Diabetes Obes Metab Jul 2014;16:636-44.
[79] Rosenstock J, Fonseca VA, Gross JL, Ratner RE, Ahren B, Chow FC, et al. Advancing basal insulin replacement in type 2 diabetes inadequately controlled with insulin glargine plus oral agents: a comparison of adding albiglutide, a weekly GLP-1 receptor agonist, versus thrice-daily prandial insulin lispro. Diabetes Care Aug 2014;37: 2317-25.

[80] Diamant M, Nauck MA, Shaginian R, Malone JK, Cleall S, Reaney M, et al. Glucagonlike peptide 1 receptor agonist or bolus insulin with optimized basal insulin in type 2 diabetes. Diabetes Care Oct 2014;37:2763-73.

[81] Xu W, Bi Y, Sun Z, Li J, Guo L, Yang T, et al. Comparison of the effects on glycaemic control and beta-cell function in newly diagnosed type 2 diabetes patients of treatment with exenatide, insulin or pioglitazone: a multicentre randomized parallelgroup trial (the CONFIDENCE study). J Intern Med Jan 2015;277:137-50.

[82] Rosenstock J, Guerci B, Hanefeld M, Gentile S, Aronson R, Tinahones FJ, et al. Prandial options to advance basal insulin glargine therapy: testing lixisenatide plus basal insulin versus insulin glulisine either as basal-plus or basal-bolus in type 2 diabetes: the GetGoal Duo-2 trial. Diabetes Care Aug 2016;39:1318-28. 